\title{
An Analysis Of Rise And Fall Of SCM - ICT Integration By The FMCG Sector In Pakistan
}

\author{
Roshan Shaikh, Iqra University, Pakistan \\ Muhammad Fahim Shamim, Iqra University, Pakistan \\ Sanam Riaz, Iqra University, Pakistan
}

\begin{abstract}
An extensive amount of research has been done in the important domain of Supply Chain Management (SCM) and its Integration with Information and Communication Technology (ICT). However, pragmatic insight to address the SCM-ICT integration challenges, based upon real world contemporary case studies, are scant. This work targets Fast Moving Consumer Good (FMCG) companies located in Pakistan. This paper examines data from the FMCG sector in Pakistan and proposes a model for Key Realization Concepts for Supply Chain Success (KRCSCS). During the course of this study, it was discovered that those FMCG companies, which integrated ICT with SCM in a sequentially structured approach, took shorter learning curves, had realistic Return on Investment (ROI) expectations, and where the top management demonstrated greater appreciation and commitment towards technology as a solution facilitator, proved to be more successful than those who did not have these characteristics. It is concluded that successful integration of ICT and SCM requires strategic commitment by the stakeholders and the top management, well thought and methodical plans of integration, rational ROI potential, and up to date technical knowhow.
\end{abstract}

Keywords: Supply Chain Management, Information and Communication Technology, E-Commerce, FMCG in Pakistan

\subsection{INTRODUCTION}

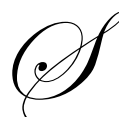

upply Chain (SC) is regarded as a group of firms participating in the upstream and downstream flow of products, services, information, and finances [1] [2] [3]. Mentzer describes SC as a set of three or more organizations directly linked by one or more of the upstream and downstream flows of products, services, finances, and ICT from a source to a customer [3]. Competition in many industries has forced businesses to introduce ways for improving product quality, customer satisfaction management (CSM) and operating efficiency to remain competitive. Due to increasing demand for quality, delivery and speed, SC has proven to be a business strategy that has gained wide acceptance. Organizations are now realizing that production efficiency alone is insufficient for maintaining a competitive edge in the industry. A comprehensive SCM integrated with modern ICtechnology is equally important. The fact that ICT is a critical component in SCM is well recognized since early 90's. Therefore the adoption of ICT is spreading rapidly in SCM. Moreover, as companies seek to improve SC efficiency through increased integration, ICT can be considered as a key enabler for SCM by supporting information sharing.

\subsection{Synthesis of ICT in SCM}

At the peer to peer level and at the cross departmental level, during the application of SC cost reducing, lead time reducing and increasing service level strategies, the most critical aspect in the management and maintenance of these strategies is the timely availability of relevant information. 
It is important to know that information flow between suppliers, manufacturers and customers is critical for the SC to flourish. This requires information to move across multiple organizations at different inter \& intra departmental levels of the hierarchy which needs to be established through strategic implementation of ICT for SCM to facilitate information sharing. Variants of this approach have already been widely practiced in the forms of emails, Electronic Data Interchange (EDI) and databases.

ICT plays an important role in SCM, as an enabler in achieving SC integration and agility [4] [5]. Much of the current interest in SCM is motivated by the possibilities that are introduced by the abundance of data and savings inherent in sophisticated analysis of the data. Innovative opportunities have been coming to the forefront with electronic commerce (e-commerce), especially through the Internet. This in turn has elevated the level of interest in ICT of corporations in Pakistan.

Implementing ICT with SCM has demonstrated improvement upon virtually all business processes such as data accuracy, operational complexity reduction, supplier selection, purchasing, warehousing and distribution and then by rewarding businesses with quicker customer response and fulfillment rates, greater productivity and lower costs, reduced inventory throughout the chain, improved forecasting precision, fewer suppliers and shorter planning cycles, improved quality and products that are more technologically advanced, enhanced inter-operational communications and cooperation, shortened repair times and enhanced equipment readiness and more reliable financial information.

However, integrated SC approach can only take place when there is strong information sharing and cooperation between the channel members via appropriate technology because without effective processes in place, the basic purpose of implementing SCM will not be served. If close coordination between all channel members fail to exist, a SC network will falter.

Much research has been done in the mid and late 1990's on the subject of SCM [6] [7] [8]. The evolution of SCs has promoted more and more injection of funds in ICT to stay up to date and up to the mark in integration of processes and different businesses through alliances or mutual understandings. Current research in the areas that deal with Competitive Advantage Provided by an Information Technology Application (CAPITA) measures identifies various factors that need to be considered. These include, Primary Activity Efficiency, Support Activity Efficiency, Resource Management Functionality, Resource Acquisition Functionality, Threat, Primitiveness and Synergy. The CAPITA measures make it clear that there are many more factors in play as compared to a normal investment and this adds complexity to the process [9].

As McCormack observed, there is no "one best way" to justify an ICT investment. Each ICT investment must be linked to the firm's market, objectives and level of risk. As is often stated, firms need to define and accomplish how they will measure success and evaluate all available options. The difficulty comes in predicting the impact of technology on people's performance, which is the only link that an ICT investment has to firm performance. Such a factor will always be difficult to predict and measure, since predicting currently unknown causal links is impossible.

The remaining of this paper includes design, parameter of key success criteria, methodology, model, analytical approach, the KRC-SCS model and conclusion.

\subsection{DESIGN PARAMETERS}

The development of design parameters for this work is motivated by the hypothesis that multinationals have been more successful in their integration and operational implementations of technology based SCs in Pakistan than the indigenous companies; even though an analysis of historical records clearly reveal that multinationals have also faced obstacles in their initial attempts to synthesize ICT with SCM. Even though literature quantifies company's successes, failures still occur [10]. Some giants such as Nike, UPS, Nestle etc, suffered initial setbacks. 


\subsection{Supply Chain Information Technology Design Goals - A Pakistan perspective}

It is commonly acknowledged that ICT is and will be an increasing element of managing logistical operations in networks. However, in Pakistan there is less empirical evidence describing actual benefits of ICT in SCM due to lack of in-depth case studies analyzing the best cases and recording the impacts and benefits of ICT and capturing the researchers' point of view. In general, even in the developed countries research has targeted success of businesses implementing technology but few have catered to the negative impact [11].

In this study the ideal model of SC - ICT integration is suggested to contain following functions:

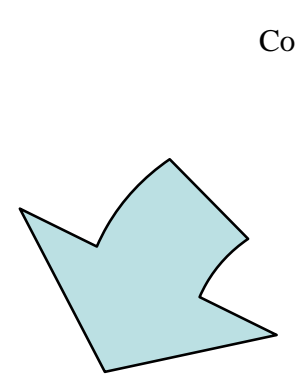

Provide sufficient and timely information

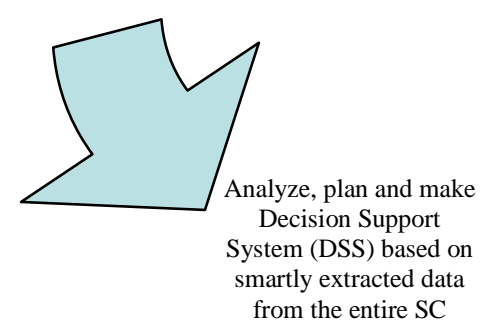

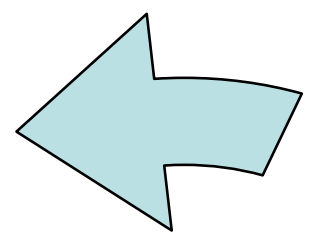

Collect Information

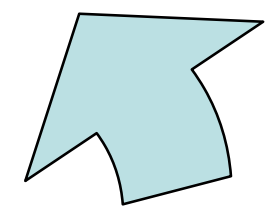

Organize and maintain data

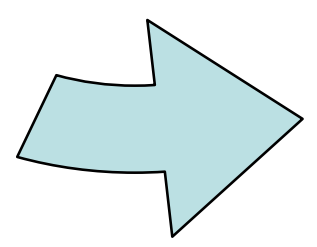

Access any data in the system

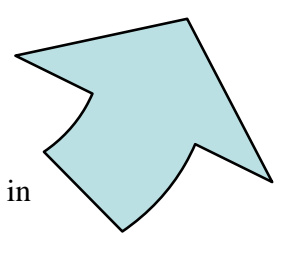

ICT and SCM integrated solutions can be classified in the following two categories based upon various propositions suggested in literatures [11] [4] [7] [8]:

\section{Class 1:}

Successful e-biz solutions for improving customer's relationship.

\section{Class 2:}

Solutions that identify critical activities such as planning, collaboration, Business Process Re-engineering and Customer Request Resolution. 


\subsection{Parameters of Key Success Criteria}

Each industry has a set of variables which influences the result of their investment. Although the success criteria for every system differ; such variables need to be identified in order to measure the degree of success which can be achieved. For a SC - ICT integrated solution to be successful, it is critical that some measurable performance is achieved before blind trusting the stated software solution.

List of performing variables along with their key success parameters and assumed threshold values are defined in Table-1.

Table 1

Key success parameters and Assumed threshold values

\begin{tabular}{|c|c|c|}
\hline SCM functions & Key success parameters & Assumed threshold values \\
\hline BPR & $\begin{array}{ll}\text { - } & \text { Cost } \\
\text { - } & \text { Production and services } \\
\text { - } & \text { Assets utilized } \\
\end{array}$ & $\begin{array}{l}\text { 0.042 } \\
\text { 0.042 } \\
\text { 0.042 } \\
\text { 0.042 }\end{array}$ \\
\hline Inventory Levels & $\begin{array}{ll}\text { - } & \text { Delivery } \\
\text { - } & \text { Warehousing } \\
\text { - } & \text { Cycle times } \\
\text { - } & \text { Order fulfillment performance }\end{array}$ & $\begin{array}{l}0.042 \\
0.042 \\
0.042 \\
0.042\end{array}$ \\
\hline Logistics & $\begin{array}{ll}\text { - } & \text { Delivery } \\
\text { - } & \text { Cost } \\
\text { - } & \text { Faster time to market }\end{array}$ & $\begin{array}{l}0.056 \\
0.056 \\
0.056\end{array}$ \\
\hline Procurement & $\begin{array}{ll}\text { - } & \text { Quality } \\
\text { - } & \text { Cost } \\
\text { - } & \text { Responsiveness } \\
\text { More reliable demand forecasts }\end{array}$ & $\begin{array}{l}0.042 \\
0.042 \\
0.042 \\
0.042\end{array}$ \\
\hline Better response to SC partners & & 0.167 \\
\hline CRM & $\begin{array}{ll}\text { - } & \text { Sales } \\
\text { - } & \text { Delivery } \\
\text { - } & \text { Quality } \\
\text { - } & \text { Customer Service } \\
\text { - } & \text { Responsiveness }\end{array}$ & $\begin{array}{l}0.033 \\
0.033 \\
0.033 \\
0.033 \\
0.033\end{array}$ \\
\hline
\end{tabular}

\subsection{Methodology}

Using identifiable variables and the key success criteria, uncovered through literature review and case studies, a survey instrument was designed and filled through personal interviews. The best and easily accessible resource was the Karachi Stock Exchange where a list of 27 registered public limited FMCG Companies was obtained. On the basis of success and market strength a sample size of $41 \%$ was selected. $63 \%$ respondents provided enough data to incur acceptable results for the purpose of this study.

To improve the statistical evaluation error correction technique such as $\mathrm{P}$ value and relevant regression and analytical approaches was applied to the raw data. The data was analyzed using correlation modeling techniques and cross tabulation. This was achieved through the usage of statistical tools such as SPSS.

Correlation techniques were used in order to identify the level of success being achieved by the key success variables and identify their influence on implementation success.

In order to get sufficient data, a base line was designed on which to evaluate the companies so that there was minimum room for discrepancies and bias. The purpose of using correlation technique was to highlight the degree of agreement between the overall score of the respondent and product experience, to cater for the possibility that the technique might reveal slightly different results necessitating a careful study of the problem. 


\subsection{Modeling Assumptions and Notations}

A list of 5 variables was defined based on which the firms were analyzed. The variables identified were:

1. Profit (controlled variable): the variable was chosen as many firms refer to the bottom line to reflect success after the implementation has taken place. Through the assessment of this variable a better grasp on the proceedings within the company can be taken.

2. Employee Demographics: the demographics were used to determine and correlate any relationships that may exist between the success/failure of the ICT infrastructure. A higher age may be associated to a greater experience, but it also reflects resistance to change especially in regards to technological solutions.

3. Productivity: SCM is said to improve organizational productivity if the SCM implementation was a success. However knowing adaptive coefficient of productivity parameters is critical so that relevant and measurable empirical values by which production is affected can be shown.

4. Cost of ICT: the cost associated with ICT implementation within a company is perceived to be very high and time consuming under normal circumstances. If during implementation obstacles are faced the cost may increase thus resulting in a much expensive solution than was originally anticipated. The reason for this could be lack of expertise to identify all associated costs to a project prior to an implementation so that the true cost of the project can be determined before a decision is taken.

5. Management Commitment: The management plays a major role in the success and failure of an organizations path to success. The idea of examining the management structure here is to assess what kind of problems is faced by the management and to identify whether any relation exists between the management and SCM system.

\subsection{Survey Process}

The research aimed to gather inputs from various organizations in the FMCG sector, which had either implemented some sort of a SCM tool or were in the process of doing so. The survey was broken down into three parts, mainly company profile, performance measuring indicators and assessment of practice intervention.

\subsection{Analytical Approach}

Variable correlation with company success is given by the proposed layer model as shown in Figure-1.

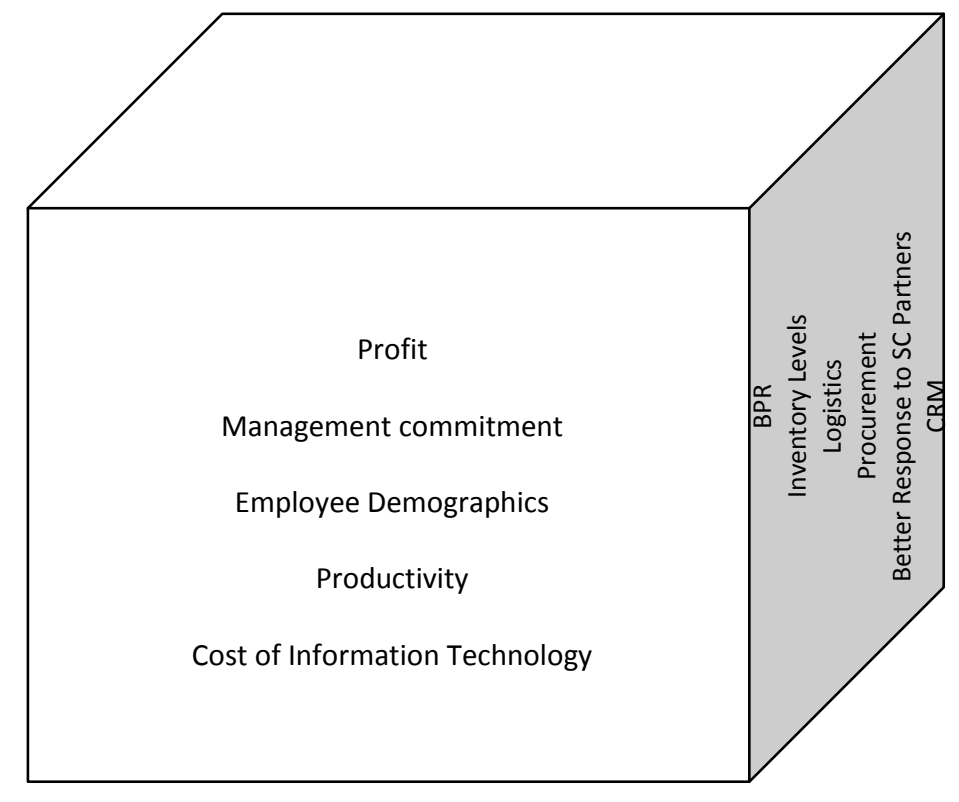

Figure 1

Key Realization Concepts for Supply Chain Success (KRC-SCS) model 
The Key Realization Concepts for Supply Chain Success KRC-SCS model essentially reflects the knowledge gained during surveys, interviews, literature review and experience gained during this work. Broadly speaking, the KRC-SCS model is a three dimensional composition of 5 layers arranged in a hierarchical manner. Along the first dimension $x-y$ (Figure-1) each layer represents SCM functions under consideration whereas the $y-z$ dimensions describe the contextual environment of key success parameters, as shown in Table-1.

As seen in Table-1, the parameters can be represented by a single polynomial equation with linear determination as under:

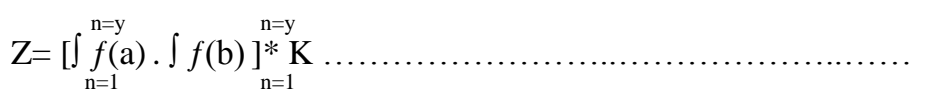

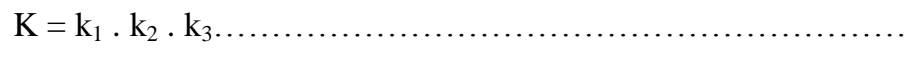

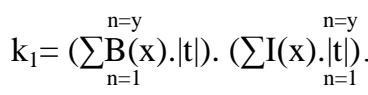

$\mathrm{k}_{2}=\left(\sum_{\mathrm{n}=1}^{\mathrm{n}=\mathrm{y}} \mathrm{L}(\mathrm{x}) \cdot \mathrm{t} \mid\right) \cdot\left(\sum \mathrm{P}(\mathrm{x}) \cdot \underset{\mathrm{n}=\mathrm{y}}{|\mathrm{t}|}\right)$

$\mathrm{k}_{3}=(\underset{\mathrm{n}=1}{\mathrm{n}=\mathrm{y}} \mathrm{S}(\mathrm{x}) \cdot|\mathrm{t}|) \cdot\left(\sum \mathrm{C}(\mathrm{x}) \cdot \mathbf{n} \mathrm{n} \mathbf{\mathrm { t }}\right)$

Where:

$\mathrm{Z}=$ combined integrated threshold for enterprises declared as successful entities after implementation of SCM with ICT

$\mathrm{K}=$ Empirical representation of the KRC-SCS model. Because the hypothesis hints at a directly proportional relationship between the KRC- SCS model and combined SCM-IT integrated thresholds for a successful implementation such that,

$\mathrm{g}(\mathrm{x}) \propto \mathrm{Z}$

$\mathrm{g}(\mathrm{x})$ being some function that represents some recursive variable that need not be calculated if the value of $\mathrm{K}$ is known. Thus,

$\mathrm{g}(\mathrm{x})=\mathrm{K}$

$\mathrm{j}=$ No. of iterations in a recursive environment from 1 to a finite no. $\mathrm{b}$

$f(\mathrm{a}), f(\mathrm{~b})=$ factorized functions for iteration 1 through y operations in planes xy and yz respectively in the KRCSCS model.

$\mathbf{0}<\mathrm{k} \leq \mathbf{1}$

$\mathrm{n}=$ key success parameter numbers

$1<\mathrm{n} \leq \mathrm{y}($ in this model $\mathrm{y}(\max )=5)$

$\mathrm{t}=$ Assumed threshold values, $\mathrm{B}=$ Business Process Reengineering $(\mathrm{BPR}), \mathrm{I}=$ Inventory Levels, $\mathrm{L}=\mathrm{Logistics}, \mathrm{P}=$ Procurement

$\mathrm{S}=$ Better response to SC partners, $\mathrm{C}=$ Customer Relationship Management $(\mathrm{CRM}), \mathrm{W}=\mathrm{Cumulative}$ of assigned weights.

During analysis, the variables were tested for +ve and -ve correlation with overall success scores. The purpose was to reveal existing relationships, if any, and the significance levels of each test to determine the strength of a relationship. The data was analyzed using correlation techniques and regression analysis. This was done with the use of statistical error correction, such as stipulation P-value using double tail correction on Fisher's scale for 
e.g. as shown in Table-2. Net profit per employees (NP/EMP) shows an increment of almost $15 \%$ after the first 2 years of ICT-SCM implementation. The P value to validate data is less than 0.5.

Table 2

P-value testing based on consolidated NP/EMP figures of all companies

\begin{tabular}{|c|c|c|}
\hline Year of ICT implementation & $\begin{array}{c}\text { Total NP/EMP for complete sample } P \text { - } \\
\text { value }=0.498143\end{array}$ & $\%$ \\
\hline 2000 & 7145.245143 & 0.118587417 \\
\hline 2001 & 7043.645551 & 0.1169012 \\
\hline 2002 & 9095.565213 & 0.150956275 \\
\hline 2003 & 8526.454508 & 0.141510921 \\
\hline 2004 & 9471.11263 & 0.157189119 \\
\hline 2005 & 9256.408182 & 0.153625735 \\
\hline 2006 & 9714.547582 & 0.16122933 \\
\hline
\end{tabular}

$\mathrm{S}=\int \stackrel{\mathrm{n}=\mathrm{y}}{f(\mathrm{x})} \mathrm{W}$

$\mathrm{W}=\sum \stackrel{\mathrm{j}=\mathrm{b}}{\mathrm{W}_{\mathrm{j}}}$

$\mathrm{n}=1$

$\mathrm{j}=1$

Table-3 shows (How successful the company is in managing its SC network viz a viz SCM software in use represented by cross tabulation) from where we derive the following empirical relationship:

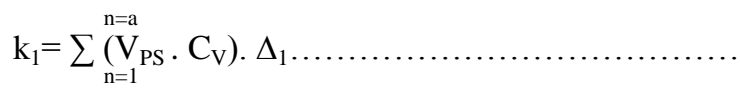

Where:

$\mathrm{a}=$ Level of Success, $\mathrm{V}_{\mathrm{PS}}=$ Perceived Success Value, $\mathrm{C}_{\mathrm{V}}=$ Overall Cost of Software, $\Delta_{1=}$ Coefficient of Proportionality

Table 3

How successful the company is in managing its SC network viz a viz SCM software in use represented by cross tabulation

\begin{tabular}{|l|l|c|c|c|c|c|}
\hline \multicolumn{2}{|l}{} & $\begin{array}{c}\text { Not } \\
\text { successful }\end{array}$ & $\begin{array}{c}\text { Somewhat } \\
\text { successful }\end{array}$ & Successful & $\begin{array}{c}\text { Very } \\
\text { successful }\end{array}$ & Total \\
\hline $\begin{array}{l}\text { SCM Software } \\
\text { in use }\end{array}$ & $\begin{array}{l}\text { Custom in house } \\
\text { software engineers }\end{array}$ & 0 & 2 & 0 & 1 & 3 \\
\hline & MYSQL based & 0 & 0 & 1 & 0 & 1 \\
\hline & SAP based & 0 & 0 & 0 & 2 & 2 \\
\hline & MS Excel based & 1 & 0 & 0 & 0 & 1 \\
\hline Total & $\mathbf{1}$ & $\mathbf{2}$ & $\mathbf{1}$ & $\mathbf{3}$ & $\mathbf{7}$ \\
\hline
\end{tabular}

Table-4 shows (How successful the company is in managing its SC network viz a viz Influence of Employee Feedback on ICT Decision) from there we drive the following empirical relationship:

$\mathrm{k}_{2}=\sum \underset{\mathrm{n}=1}{\mathrm{n}=\mathrm{a}}\left(\mathrm{V}_{\mathrm{EF}} \cdot \mathrm{F}_{\mathrm{V}}\right) \cdot \Delta_{2}$

Where:

$\mathrm{V}_{\mathrm{EF}}=$ Employee Feedback, $\mathrm{F}_{\mathrm{V}}=$ Feedback Value (Employee), $\Delta_{2=}$ Coefficient of Proportionality 
Table 4

How successful the company is in managing its SC network viz a viz Influence of Employee Feedback on ICT Decision

\begin{tabular}{|l|l|c|c|c|c|c|}
\hline \multicolumn{2}{|l}{} & $\begin{array}{c}\text { Not } \\
\text { successful }\end{array}$ & $\begin{array}{c}\text { Somewhat } \\
\text { successful }\end{array}$ & Successful & $\begin{array}{c}\text { Very } \\
\text { successful }\end{array}$ & Total \\
\hline $\begin{array}{l}\text { Did Employee Feedback } \\
\text { Influence ICT decision? }\end{array}$ & Little & 1 & 0 & 0 & 0 & 1 \\
\hline & Average & 0 & 2 & 1 & 1 & $\mathbf{4}$ \\
\hline & Greatly & 0 & 0 & 0 & 2 & $\mathbf{2}$ \\
\hline Total & $\mathbf{1}$ & $\mathbf{2}$ & $\mathbf{1}$ & $\mathbf{3}$ & $\mathbf{7}$ \\
\hline
\end{tabular}

Table-5 shows (How successful the company is in managing its SC network viz a viz Influence of Customer Feedback on ICT Decision) from there we drive the following empirical relationship:

$\mathrm{k}_{3}=\sum_{\mathrm{n}=1}^{\mathrm{n}=\mathrm{a}}\left(\mathrm{V}_{\mathrm{CF}} \cdot \mathrm{F}_{\mathrm{V}}\right) \cdot \Delta_{3}$

Where:

$\mathrm{V}_{\mathrm{CF}}=$ Customer Feedback, $\mathrm{F}_{\mathrm{V}=}$ Feedback Value (Customer), $\Delta_{3=}$ Coefficient of Proportionality

Table 5

How successful the company is in managing its SC network viz a viz Influence of Customer Feedback on IT Decision

\begin{tabular}{|l|c|c|c|c|c|c|}
\hline \multicolumn{2}{|l}{} & $\begin{array}{c}\text { Not } \\
\text { successful }\end{array}$ & $\begin{array}{c}\text { Somewhat } \\
\text { successful }\end{array}$ & Successful & $\begin{array}{c}\text { Very } \\
\text { successful }\end{array}$ & Total \\
\hline $\begin{array}{l}\text { Did Customer Feedback } \\
\text { Influence IT decision? }\end{array}$ & Not at all & 1 & 0 & 0 & 0 & 1 \\
\hline & Average & 0 & 2 & 0 & 0 & $\mathbf{2}$ \\
\hline & Greatly & 0 & 0 & 1 & 3 & $\mathbf{4}$ \\
\hline Total & $\mathbf{1}$ & $\mathbf{2}$ & $\mathbf{1}$ & $\mathbf{3}$ & $\mathbf{7}$ \\
\hline
\end{tabular}

Table-6 shows (How successful the company is in managing its SC network viz a viz Level of Training provided to Employees prior to implementation of SCM - ICT) from there we drive the following empirical relationship:

$\mathrm{k}_{4}=\sum \underset{\mathrm{n}=1}{\mathrm{n}=\mathrm{a}}\left(\mathrm{V}_{\mathrm{ET}} \cdot \mathrm{C}_{\mathrm{T}}\right) \cdot \Delta_{4}$

Where:

$\mathrm{V}_{\mathrm{ET}}=$ Value of Employee Training, $\mathrm{C}_{\mathrm{T}}=$ Cost of Training (Employee), $\Delta_{4=}$ Coefficient of Proportionality

Table-6

How successful the company is in managing its SC network viz a viz Management support towards SCM Implementation

\begin{tabular}{|l|l|c|c|c|c|c|}
\hline \multicolumn{2}{|l|}{} & $\begin{array}{c}\text { Not } \\
\text { successful }\end{array}$ & $\begin{array}{l}\text { Somewhat } \\
\text { successful }\end{array}$ & Successful & $\begin{array}{c}\text { Very } \\
\text { successful }\end{array}$ & Total \\
\hline $\begin{array}{l}\text { Management support } \\
\text { towards SCM } \\
\text { Implementation }\end{array}$ & $\begin{array}{l}\text { Somewhat } \\
\text { Supportive }\end{array}$ & 1 & 1 & 1 & 0 & $\mathbf{3}$ \\
\hline & Supportive & 0 & 1 & 0 & 0 & $\mathbf{1}$ \\
\hline & Very Supportive & 0 & 0 & 0 & 3 & $\mathbf{3}$ \\
\hline Total & $\mathbf{1}$ & $\mathbf{2}$ & $\mathbf{1}$ & $\mathbf{3}$ & $\mathbf{7}$ \\
\hline
\end{tabular}


Table-7 shows (How successful the company is in managing its SC network viz a viz Management Support towards SCM - ICT Implementation) from there we drive the following empirical relationship:

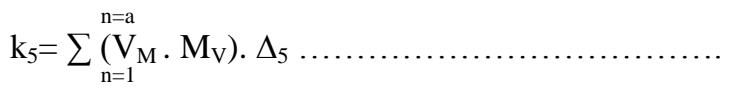

Where:

$\mathrm{V}_{\mathrm{M}=}$ Level of Management Support, $\mathrm{M}_{\mathrm{V}}=$ Value of Management Support, $\Delta_{5=}$ Coefficient of Proportionality

Table 7

How successful the company is in managing its SC network viz a viz Training provided to employees prior to the training

\begin{tabular}{|l|l|c|c|c|c|c|}
\hline \multicolumn{2}{|c|}{} & $\begin{array}{c}\text { Not } \\
\text { successful }\end{array}$ & $\begin{array}{c}\text { Somewhat } \\
\text { successful }\end{array}$ & $\begin{array}{c}\text { Very } \\
\text { Successful }\end{array}$ & successful & Total \\
\hline \multirow{2}{*}{$\begin{array}{l}\text { Training provided to } \\
\text { employees prior to the }\end{array}$} & Average & 1 & 1 & 1 & 0 & 3 \\
\cline { 2 - 8 } Implementation & Greatly & 0 & 1 & 0 & 2 & 3 \\
\cline { 2 - 8 } & A lot & 0 & 0 & 0 & 1 & 1 \\
\hline Total & $\mathbf{1}$ & $\mathbf{2}$ & $\mathbf{1}$ & $\mathbf{3}$ & $\mathbf{7}$ \\
\hline
\end{tabular}

\subsection{CONCLUSION \& RECOMMENDATION}

Based upon the experience gained during the design phase, a way forward can be suggested for the FMCG organizations in Pakistan that can benefit from this research followed by an analysis of the proposed model. It is worthwhile to note that discoveries made during this work may also lead to new research, especially in the areas of SCM-ICT. It is recommended that empirical weights should be assigned to the internal and external processes based on their importance and impact on the business identifying numerical magnitudes. This research has discovered that even with the two significant downers, mainly, initial shock of bringing new technology \& accompanying practices dipping deep down in the pockets of organizational budgets and the cultural environment and inertia causing ripple effect on the profitability of the enterprises, after the first 2 years measurable improvements are observed in the net bottom line of the concern, as shown by the P-value in Table- 2 .

As the technologies are changing too rapidly to guarantee a sure shot solution for success in the long term, a business should plan incremental integration of Technology solutions with more than a short time line ahead instead of working on mega projects with completion deadlines too far in future. This rule is supported by Gartner's narration that a technology aimed for more than a year is likely to fail due to rapid development in technology.

The company's e-business strategy should not be independent of the business strategy. A company should plan and implement only those technologies critical to the firm and one which is in complete compliance with the company's business strategy as shown in Table-3. This means only solutions benefiting the core competency should be pursued. In certain cases Strategic Business Units (SBU) should not be bound by rigid rules and should be given a chance to innovate on their own. In this case SBU are given freedom to innovate and implement and not follow a rigid structure. In order to succeed in overall SCM implementation it is essential that the employees are well trained and educated prior to the implementation as is represented by Table- 4 \& Table- 7 .

It is necessary that the management takes ownership of the implementation process and is supportive and shows interest in all phases of SC-ICT integration. Until and unless interest and support is not shown, the overall implementation will carry a dull feel from day one and underperforming solutions as shown in Table- 6 .

Distribution and procurement channels need not be carried based on their seniority and investment instead make them more flexible and efficient to adapt to the rapid market changes and minimize costs by increasing partnerships which are dynamic. 


\section{AUTHOR INFORMATION}

Dr. Roshan Shaikh. With a Ph.D. in Artificial Intelligence and a vast post doctoral training and consulting experience as an IT systems architect, designer and developer Dr. Shaikh brings 30 years of industry references, contacts and systems experience, 25 years of which is from USA. He is an author, policy-maker and technology strategist. His specialties include supply chain management, technical planning, education systems, ICT systems organization, Telecommunications, Networks and Security.

Muhammad Fahim Shamim. He works as a Planning Manager in the Supply Chain Department for IFFCO, a Multinational FMCG firm based in Sharjah, U.A.E. His work focuses on developing Integrated Supply Chain systems across the Group Business Units based on demand forecasting, production, planning, purchase planning, distribution planning \& material accounting. He is also responsible for ensuring end to end efficiencies in working capital deployed in inventories. He holds a BCS degree in Networking and a MBA degree in Supply Chain Management from IQRA University, Pakistan.

Sanam Riaz. She works as a Planning Manager in the Logistics Department for Herbion Pakistan, an internationally renowned name in the herbal medicine industry. Her work revolves around forecast collection and translation into a logistics plan which results in to a production schedule, for International exports and imports. Uses analytical \& quantitative methods to understand, predict and enhance logistic activities/processes. She holds a Bachelor's degree in Computer Sciences and a Master's degree in Business Administration with majors in Supply Chain Management from IQRA University, Pakistan.

\section{REFERENCES}

1. La Londe, Bernard J. and James M. Masters (1994), "Emerging Logistics Strategies: Blueprints for the Next Century," International Journal of Physical Distribution and Logistics Management, Vol. 24, No. 7, pp. 35-47.

2. Lambert, Douglas M., James R. Stock, and Lisa M. Ellram (1998), Fundamentals of Logistics Management, Boston, MA: Irwin/McGraw-Hill, Chapter 14.

3. Mentzer, John T. (2001), Supply Chain Management, Thousand Oaks, CA: Sage Publications.

4. Gunasekaran, A. \& Ngai, E.W.T. (2004), 'Information Systems in Supply Chain Integration and Management', European Journal of Operational Research, Vol.159, pp.269-295

5. Power (2001), 'Critical Success Factors in Agile Supply Chain Management', International Journal of Physical Distribution \&Logistics Management, Vol.31, No.4, pp.247-265

6. Malone, T.W. and Rockart, J.F. (1991) Computers, networks, and the corporation. Scientific American 265(3), 128-36.

7. Kolberg, Maria and Dreyer, Heidi. "Exploring the Impact of ICT on Integration in Supply Chain Control: A Research Model", Department of Production and Quality Engineering, Norwegian University of Science and Technology.

8. Strader, Lin "Business-to-business electronic commerce and convergent assembly supply chain management

9. McCormack, Kevin, “The information Technology Investment Decision Process: Why isn't it working?"

10. Happek, Susan \& Meloro, Linda \& Oliver, John,"Up and Running: Helping supply chain technology do its job"

11. Auramo, Jaana \& Kauremaa, Jouni \& Tanskanen, Kari, "Benefits of IT in Supply chain management- an explorative study of progressive Finnish Companies" 